\title{
Assessment of food insecurity and its determinants in the rural households in Damot Gale Woreda, Wolaita zone, southern Ethiopia
}

\author{
Adimasu Awoke Mota, Senbetie Toma Lachore and Yoseph Halala Handiso *
}

\begin{abstract}
Background: Food insecurity is directly related to poverty at global, regional, national and local levels. FAO's most recent estimates indicate that globally, 842 million people were unable to meet their dietary energy requirements in 2011-2013. Thus, around one in eight people in the world is likely to have suffered from chronic hunger, not having enough food for an active and healthy life. Around 827 million hungry people which are vast majority live in developing countries where the prevalence of undernourishment is now estimated at 14.3\% in 2011-2013. So, we were interested to assess food insecurity and its determinants in the rural households in Damot Gale Woreda, Wolaita zone, southern Ethiopia.
\end{abstract}

Methodology: Cross-sectional household survey was used to collect primary data from 155 randomly selected households; focus group discussion and key informant interview were conducted. The data analysis techniques involved both descriptive and bivariate and multivariate logistic regression analyses.

Results: The results of the study revealed that the majority (71.6\%) of rural households in the study area were food insecure. The Household Food Insecurity Access Scale (HFIAS) shows that HH cannot cover the required daily food from the production generated from their agriculture as well as other activities. Households with large family size, households who cannot read and write and old household heads are more likely to be food insecure than their counter parties. Similarly low land size, lack of livestock, not having confidence to overcome food insecurity of HH, borrowing money from informal rural money lenders and not using farm input by the $\mathrm{HH}$ are significantly associated with food insecurity. Finally, promoting income-generating activities, enhancing the micro-financing efficiency, initiating family planning, strengthening the inter-resettlement programs, enhancing saving habits, creating employment opportunities at local areas to deter unskilled labor migration on-farm diversification.

Conclusions: The findings of the study revealed that $71.6 \%$ of the households are food insecure through the use of HFIAS measurement. These food insecure households could not cover the required daily food from the income generated from their major activity of subsistence agriculture and non-farm activities both in quality and quantity.

Keywords: Determinants, Food insecurity, Household, Damot Gale Woreda

\section{Background}

Food insecurity is directly related to poverty at global, regional, national and local levels [1]. FAO's most recent estimates indicate that globally, 842 million people-12\% of the global population-were unable to meet their dietary energy requirements. Thus, around one in eight

${ }^{*}$ Correspondence: yosephhalala@yahoo.com

Wolaita Sodo University, Wolaita Sodo, Ethiopia people in the world is likely to have suffered from chronic hunger, not having enough food for an active and healthy life. The vast majority of hungry people -827 million of them-live in developing regions, where the prevalence of undernourishment is now estimated at $14.3 \%$ in 2011-2013.

Despite notable progress in economic growth and welfare improvement in developing countries over the last decades, food security has not been attained in most 
developing countries. Particularly food insecurity continues to form a deep seated problem in several Sub-Saharan African countries. A report of the FAO indicates that the number of undernourished in Africa still remains high at 279 million [2].

Ethiopia is one of the poorest countries in the world with a large portion of its population believed to be living below poverty line [3]. According to the FAO, 2010, 41\% of the Ethiopian population lives below the poverty line and more than 31 million people are undernourished.

\section{Statement of the problem}

A large portion of the Ethiopian population have been affected by chronic and transitory food insecurity. The situation of chronically food insecure people is more and more severe. Food security situation in Ethiopia is highly linked up to severe, recurring food shortage and famine, which is associated with recurrent drought. Currently, there is a growing consensus that food insecurity and poverty problems are closely related in the Ethiopian context. More than $50 \%$ of the total population, of whom the majority reside in rural areas, does not have access to the medically recommended minimum average daily intake of 2100 cal per person per day [3].

Mostly food insecure households are concentrated in central part of southern Ethiopia, generally described as drought- and famine-prone areas. One of these is the mixed farming production system area which is Wolaita zone. Most of the land resources (mainly the soils and vegetation) of this part of the country have been highly degraded because of the interplay between some environmental and human factors such as relief, climate, population pressure and the resultant over-cultivation of the land, deforestation of vegetation and overgrazing. The area is generally considered as resource poor with limited or no potential and hence highly vulnerable to drought. The present study area, Damot Gale Woreda, is one of the food insecure Woreda of Southern region because the number of chronically food insecure population aided by productive safety net program (PSNP) for the past years was about 38,773 beneficiaries next to Humbo Woreda [4].

The area is vulnerable for child and maternal malnutrition (stunting, wasting and under weight), infection of malaria, starvation, dependency, drop out of education, migration and need of emergency food aid. This implies the existence of socioeconomic, demographic and other factors underlying the poverty and food insecurity problem in the study area. Having this background, this study has been done to investigate the food insecurity and its determinants in rural households in Damot Gale Woreda.

\section{Objectives of the study}

To assess food insecurity and its determinants in the rural households in Damot Gale Woreda, Wolaita zone, southern Ethiopia.

Research questions: 1 . What is the status of food insecurity problem in the rural households of the area?

2. What are the factors for food insecurity problem in the rural households of the area?

\section{Significance of the study}

This study would provide findings on status of food insecurity and its determinants of rural household. Identifying and understanding factors that cause food insecurity would afford information for policy makers, planners, governmental and nongovernmental organizations which are working in the areas of food security program in order to modify and re-plan food security program interventions and take measurements on causes of food insecurity. In addition, it indicates gaps to be filled by further studies.

\section{Methods and materials Study area}

Study was conducted in Damot Gale Woreda which is bordered on the southwest by Sodo Zuria, on the northwest by Boloso Sore and Damot Pulasa, on the north by the Hadiya Zone, on the east by Diguna Fango and on the southeast by Damot Weyde. Astronomically, the Woreda is located between $6^{\circ} 55^{\prime} 00^{\prime \prime}$ and $7^{\circ} 10^{\prime} 00^{\prime \prime} \mathrm{N}$ Latitude and $37^{\circ} 45^{\prime} 0^{\prime \prime}$ and $38^{\circ} 0^{\prime} 0^{\prime \prime} \mathrm{E}$ Longitude. Damot Gale Woreda is located at $350 \mathrm{~km}$ south of Addis Ababa and $153 \mathrm{~km}$ southwest of Hawassa capital of southern Ethiopia. The Woreda covers an area of about 24,185.9 hectare. Administratively, it is subdivided into 31 Kebeles [5] (Fig. 1).

The study area is divided into different agro-climatic regions on the base of temperature and altitudes. Mean monthly temperatures vary from $16{ }^{\circ} \mathrm{C}$, during the coldest months and $20{ }^{\circ} \mathrm{C}$, during the hottest (warmest) month. Average annual rainfall is also found $1250 \mathrm{~mm}$. The altitude ranges between 1500 and $3500 \mathrm{~m}$ above sea level [6]. The total population of the Woreda is 151,079 of which 74,227 are male and 76,852 female with the density of Damot Gale 664 persons $/ \mathrm{km}^{2}$ [7]. Agricultural land constitutes the dominant resource base for the creation of economic opportunities for the rural household in the study area. Agriculture comprises about $90 \%$ of the economic activity in the study area.

\section{Research design}

Community-based cross-sectional study design was used. This study was a mixed type of research involving both qualitative and quantitative methods. The strategy followed in this research is concurrent triangulation to 


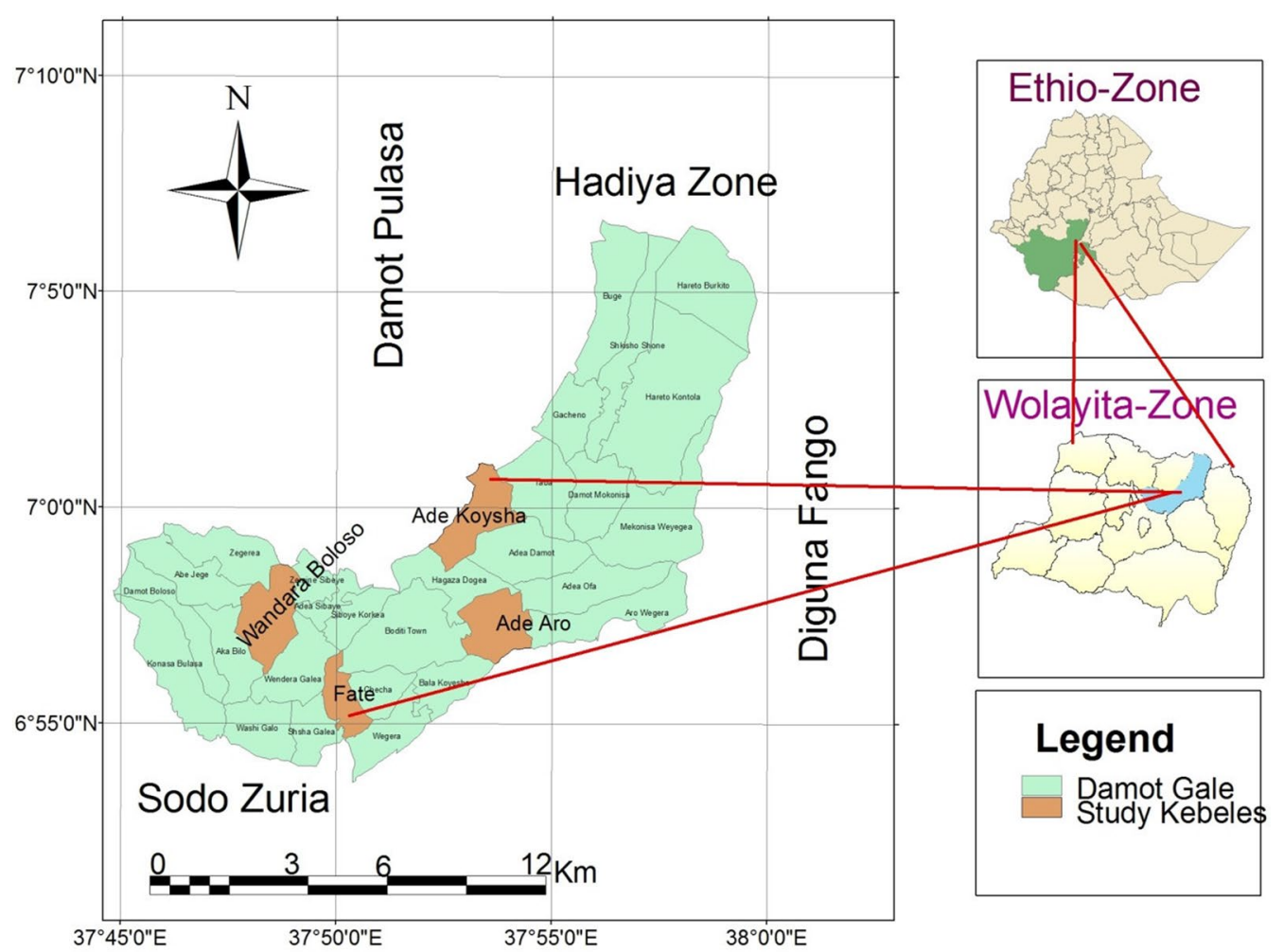

Fig. 1 Location map of Damot Gale Woreda. Source: Extracted from Ethio-GIS by the Author, 2014

explain concepts, characteristics, descriptions and measures to express situations of the issue.

\section{Data sources and methods of collection}

Qualitative and quantitative approaches were used to collect data from both primary and secondary sources. The questionnaires were pretested and modified in the field in order to help refining the questions.

\section{Sampling procedure: sampling procedure}

Multistage sampling technique was used for this particular study. In the first stage, Damot Gale Woreda was selected purposively on the basis of food insecurity condition. In the second stage, the study Kebeles was stratified into two different strata in order to cover varying agro-climate. In the third stage, the four Kebeles were randomly selected from 31 study Kebeles. In the fourth stage, sample HHs were selected from each Kebeles. To select sample HHs, systematic sampling method was applied by taking the $n$th element of the sample frame. To select study HHs, systematic random sampling method was applied by taking the $n$th element of the sample frame. There are 2837 households in four selected Kebeles. The list of household was obtained from Woreda agricultural office in the study areas. 2837 was divided by sample size (155) and it gave 18 . So that the $n$th value is 18 . One number was obtained by randomly between 1 and 18 . The number was 5 . So that every 18 th number was selected to get sampled household. It also assures that the population will be evenly sampled [8] (Fig. 2).

\section{Sample size determination}

In order to decide the sample size, a quantitative model suggested by Cochran [9] and indicated by Yamane [10:886] was adopted as presented below:

$$
n=\frac{N}{1+N(e)^{2}}
$$

where $n$ sample size; $N$ total number of households in the selected Kebeles [the sample size $(n)$ in each Kebele was picked on the basis of its proportion to $N$ because the number of households in each Kebele is different], $e$ maximum variability or margin of error $8 \%(0.08), 1=$ probability of the event occurring.

Based on the above sample size determination calculation, 148 sample households were obtained. To provide for the likely non-response, $5 \%$ of 148 was added, which is 7 respondents to serve as reserve respondents. This makes a total sample size of 155 respondents. 


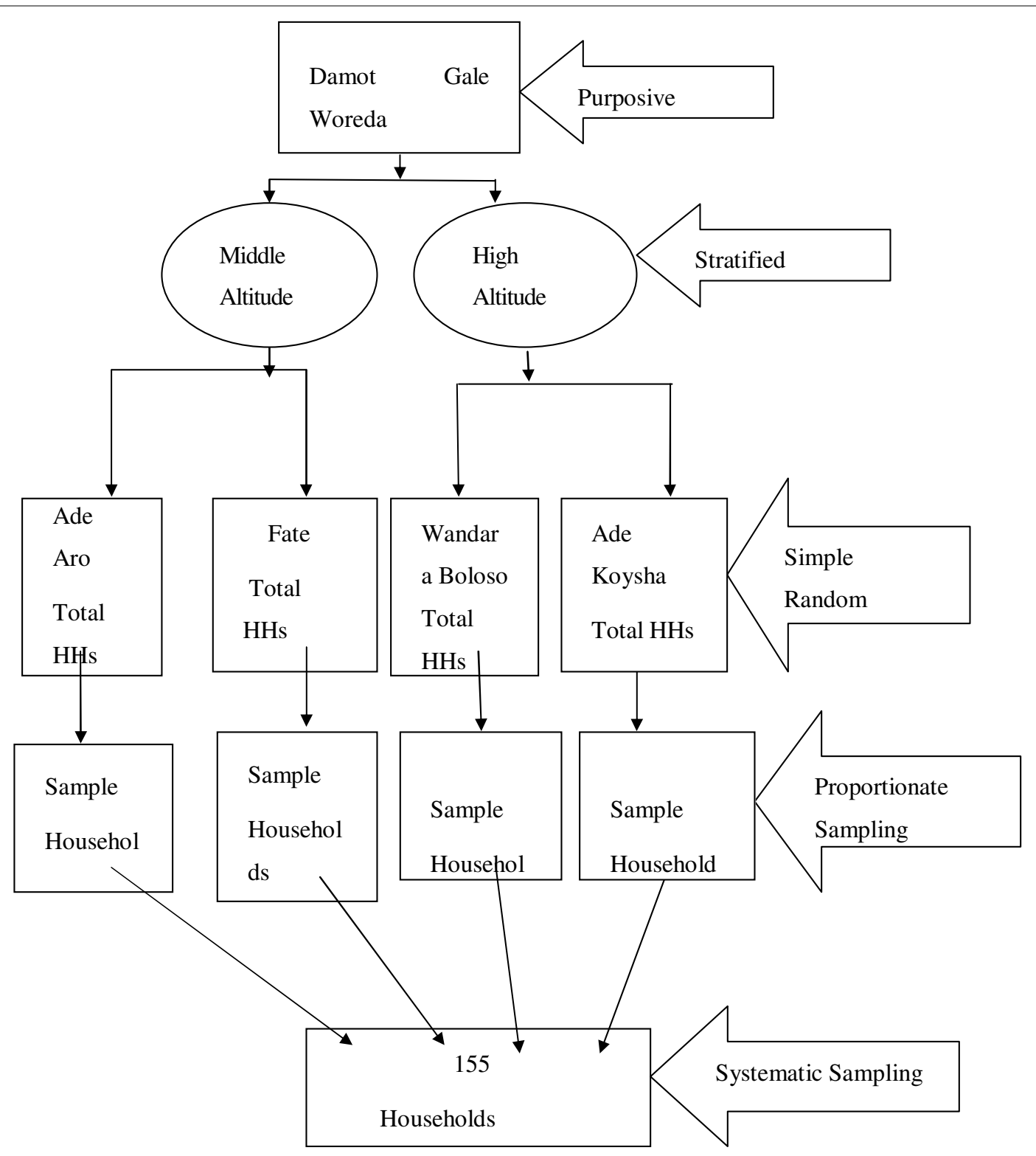

Fig. 2 Schematic presentation of sampling procedure

\section{Data analysis and presentation of findings}

After completion of fieldwork, the data were coded and entered into Statistical Package for Social Sciences (SPSS) software for windows version 20. Hereafter, data were cleaned and verified for analysis.

The descriptive narrative analysis approach was conducted for the qualitative data generated through focus group discussion and key informants. In addition descriptive analysis method was used to describe data collected from sample households. Qualitative data were also analyzed manually by identifying thematic area of the study. The quantitative data generated through household interview and questionnaire survey were analyzed by employing Statistical Package for Social Science (SPSS version 20) computer software. Then, results of data analysis were presented by creating a frequency and percent table format of variables.

Descriptive statistical analysis was carried through cross tabulation by frequency and percentage. Logistic regression analysis was used to analyze relationships between a dichotomous-dependent variable and independent variables. In this case, multiple independent variables were presented simultaneously to predict 
membership of dependent variable which was dichotomous (categorical).

\section{Study variables \\ Dependent variable}

Household food insecurity was measured by Food Insecurity Access Scale even though there are many food security measurement tools.

Dependent variable was coded as the following: Household food security status $(0=$ food secure, $1=$ food insecure).

\section{Independent variables}

Agricultural inputs (improved seeds and fertilizers); Have confidence to escape from food insecurity; Household Size; Sex of Household Head; Educational Level of Household Head; Age of Household Head's in years; Livestock own; Land size; Distance to the market; Credit use by the household; Involvement of the household members in petty trading; Borrowing money from informal rural money lenders; and Marital form (monogamy; polygamous and others).

\section{Measuring the response variable: household food insecurity}

This study was employed, the Household Food Insecurity Access Scale (HFIAS), which is an adaptation of the approach used to estimate the prevalence of food insecurity in the area. The method is based on the idea that the experience of food insecurity (access) causes predictable reactions and responses that can be captured and quantified through a survey and summarized in a scale [11].

\section{Ethical consideration}

Prior to starting the work, the study design was explained to Officials of Agriculture department and Administrative of Damot Gale Woreda for their permission and support. The nature of the study was fully explained to respondents to obtain consent. No false promise such as remuneration and or per diem, food and financial aids was given. Information was collected after securing consent from study participant. Data obtained from each study participant were kept confidential, and all peoples who participated in the study were acknowledged.

\section{Results and discussion}

Table 1 presents some basic descriptive statistics of socio-demographic characteristics of the households. Out of sample households $(N=155)$, majority $(85.2 \%)$ were male and $14.8 \%$ were female headed. The married (two-parent) households accounted for fourfold (91\%) of the whole sampled households. In our study,
Table 1 Distribution of sample HHs in the selected Kebeles

\begin{tabular}{llcc}
\hline Kebeles & Location & Total HHs & Sample HHs \\
\hline Ade Aro & Middle altitude & 796 & 43 \\
Fate & Middle altitude & 489 & 27 \\
Wandara Boloso & High altitude & 840 & 46 \\
Ade Koysha & High altitude & 712 & 39 \\
Total & & 2837 & 155 \\
\hline
\end{tabular}

Source: Kebeles offices of the respective Kebeles (2014)

the marital form, about $7.3 \%$ of the respondents, was found to live in a polygamous union. The majority of the respondents $(87.7 \%)$ are reported to be Protestants followed by Orthodox (10.3\%) and Catholic (1.9\%). The higher percentage distribution of the Protestant religion commensurate the Woreda picture where about 69\% of the population of the Woreda is Protestants [7].

Regarding the age distribution of the household heads, majority of them are represented from the age group 35-49 years (54.8\%), whereas the respondents in the age group $25-34$ years accounts for about $17.4 \%$ and 50-64 years Comparatively, the young (15-24 years) and the aged (65 and above) account for a significant proportion of the respondents (16.8, 5.8 and $5.2 \%$, respectively). Looking at the percentage distribution of the respondents, it is evident that the majority of them fall in the middle adulthood category. Additionally, majority of the households $(44.5 \%)$ are reported to have a size of 7-10 members followed by $4-6$ (36.8\%) and only $9.7 \%$ and $9.0 \%$ of the households are $0-3$ and $10+$ sized households, respectively. It is also observed that the computed mean household size for the study is about 7.1, which is well above the mean at national level 4.8 [12].

When we see the educational status of the study participants, in Table 1 reports of the respondents, it was found out that $56.1 \%$ of the respondents are literate, while the remaining $43.9 \%$ are categorized as illiterate. The percentage distribution of the $\mathrm{HH}$ heads by educational status reveals that $40.6 \%$ of the respondents are at primary level of education. The secondary and college levels account for about 14.2 and $1.3 \%$ of the respondents, respectively.

\section{Household economic indicators}

Table 2 lists selected economic characteristics of households. Less than half (42.6\%) of sample households owned less than 0.25 hectare of farm land, $36.1 \%$ own $0.25-0.5$ hectare, about $17.4 \%$ half to one hectare and $3.9 \%$ owned 1-2 hectare. On average, land holding size per household was found to be 0.31 hectare, which appears very small. In addition to this, $29.7 \%$ of them reported that they did 
Table 2 Socio-demographic characteristics

\begin{tabular}{|c|c|c|}
\hline Characteristics & Frequency & Percent \\
\hline \multicolumn{3}{|l|}{ SexHHhead } \\
\hline Male & 132 & 85.2 \\
\hline Female & 23 & 14.8 \\
\hline \multicolumn{3}{|l|}{ Marital status HH head } \\
\hline Married & 141 & 91 \\
\hline Divorced & 6 & 3.9 \\
\hline Widow & 6 & 3.9 \\
\hline Widower & 2 & 1.3 \\
\hline \multicolumn{3}{|l|}{ Marital form of HH head } \\
\hline Polygamous & 12 & 7.3 \\
\hline Monogamous & 143 & 92.7 \\
\hline \multicolumn{3}{|l|}{ Religion of HH head } \\
\hline Orthodox & 16 & 10.3 \\
\hline Protestant & 136 & 87.7 \\
\hline Catholic & 3 & 1.9 \\
\hline \multicolumn{3}{|l|}{ Age of HH head } \\
\hline $15-24$ & 9 & 5.8 \\
\hline $25-34$ & 27 & 17.4 \\
\hline $35-49$ & 85 & 54.8 \\
\hline $50-64$ & 26 & 16.8 \\
\hline $65-100$ & 8 & 5.2 \\
\hline \multicolumn{3}{|l|}{ HH size distribution } \\
\hline $0-3$ & 15 & 9.7 \\
\hline $4-6$ & 57 & 36.8 \\
\hline $7-10$ & 69 & 44.5 \\
\hline Above 10 & 14 & 9 \\
\hline \multicolumn{3}{|c|}{ HH head educational status } \\
\hline Cannot read and write & 68 & 43.9 \\
\hline Primary school & 63 & 40.6 \\
\hline Secondary level & 22 & 14.2 \\
\hline Higher level (diploma) & 2 & 1.3 \\
\hline
\end{tabular}

Source: Field survey, 2014

not have any income (neither on-farm nor off-farm), those with 1-100 birr per month account for 31.6\%, 101500 birr per month $22.6 \%$ and 501-1000 and $1000+$ were very small proportion $11.6 \%$ and $4.5 \%$, respectively. About $37.4 \%$ of the sample farmers reported to use chemical fertilizer and improved seed. $7.7 \%$ used improved seed only, 23.2 used chemical fertilizer and local seed and $32.3 \%$ not used any modern farm inputs due to lack of income. Crop production is an important farming practice adopted invariably by every farmer in the Woreda. In addition to this, some of the participants were practicing animal rearing. But about $41.9 \%$ of households did not have any ox at all, $42.6 \%$ owned only one ox, and a small proportion of households (15.4\%) have two or more oxen. Similarly, 57.4 and $31 \%$ of households have no milking cows and non-milking cows, respectively. But 23.9 and
$38.7 \%$ have only one milking cow and non-milking cow, respectively, whereas 18.7 and $30.3 \%$ owned two or more number of milking cows and non-milking cows, respectively. The proportion of households with no goats, donkeys, sheep, horses and mule is indicated to be 96.8, 91.8, $71,98.7$ and $98.7 \%$, respectively.

\section{Household food security measures and indicators}

Table 3 reveals the distribution of respondents by household food insecurity indicators (access scale). It is known that the household food insecurity can be measured in different ways depending on the purpose of the study. For instance, the food insecurity can be measured by household survey food consumption data, caloric intake, dietary diversity, household food insecurity access scale, food adequacy question and the like. This study employed commonly known measure of food security status used cross culturally: Household Food Insecurity Access Scale, HFIAS.

The Household Food Insecurity Access Scale (HFIAS) is based on the idea that there is a set of predictable reactions to the experience of food insecurity that can be summarized and quantified, allowing for measurement through household surveys. The HFIAS was adapted from the current United States methodology for estimating national prevalence of food insecurity, and measures (1) household access to food and (2) the degree of anxiety involved in its acquisition. Its classification system uses a set of nine questions used in surveys around the world that have been proven to be effective in distinguishing the food secure from the food insecure at the household level. The HFIAS questions thus represent universal aspects of the experience of food insecurity, capturing information on food shortage, food quantity and quality of diet to determine the status of a given household's access to food. Households and populations can be classified according to the severity of their food security status along a spectrum, by using data on the severity and frequency of their experiences over the previous 30 days [13].

Table 3 lists nine important variables measured by a dichotomous response. The nine variables measure access to food ranging from "simple worry for food shortage" to "experience of spending the day and night without eating any food." The responses to these nine questions are aggregated together to form the dependent variable.

It is indicated in Table 3 that $69.9 \%$ of the respondents reported to have worried about food shortage during the last 4 weeks; $71.6 \%$ reported inability to eat the preferred food: $68.3 \%$ reported to have eaten limited variety of food; $48 \%$ were unable to eat the preferred variety of food due to lack of adequate resources; $66.4 \%$ reported that their household members eaten 
Table 3 Household economic characteristics

\begin{tabular}{|c|c|c|}
\hline Characteristics & Frequency & Percent \\
\hline \multicolumn{3}{|l|}{ Land size of HH } \\
\hline Less than 0.25 hectare & 66 & 42.6 \\
\hline $0.25-0.50$ hectare & 56 & 36.1 \\
\hline Half to one hectare & 27 & 17.4 \\
\hline 1-2 hectare & 6 & 3.9 \\
\hline \multicolumn{3}{|c|}{ Involvement of the HH members in petty trading } \\
\hline Yes & 42 & 27.1 \\
\hline No & 113 & 72.9 \\
\hline \multicolumn{3}{|l|}{ Accessibility to main economic factors } \\
\hline $0-30 \mathrm{~min}$ & 33 & 21.3 \\
\hline $30-60 \mathrm{~min}$ & 47 & 30.3 \\
\hline Greater than $1 \mathrm{~h}$ & 75 & 48.4 \\
\hline \multicolumn{3}{|l|}{ Credit by HABP for $\mathrm{HH}$} \\
\hline Yes & 60 & 39 \\
\hline No & 95 & 61 \\
\hline \multicolumn{3}{|l|}{ Farm Input use by the HH } \\
\hline Yes & 105 & 67.7 \\
\hline No & 50 & 32.3 \\
\hline \multicolumn{3}{|l|}{ Major income source of the $\mathrm{HH}$} \\
\hline Only crop production & 6 & 3.8 \\
\hline Only livestock rearing & 4 & 2.6 \\
\hline Mixed farming & 92 & 59 \\
\hline Trade (wholesale, retail sale...) & 7 & 5 \\
\hline \multicolumn{3}{|l|}{ Main source of food for the HH consumption } \\
\hline HH production only & 19 & 12.3 \\
\hline HH production and from market & 99 & 63.9 \\
\hline $\mathrm{HH}$ production, from market and PSNP & 37 & 23.9 \\
\hline \multicolumn{3}{|c|}{$\begin{array}{l}\text { Experience of borrowing money from informal rural money lenders for food } \\
\text { purchase }\end{array}$} \\
\hline Yes & 85 & 54.9 \\
\hline No & 70 & 45.1 \\
\hline \multicolumn{3}{|l|}{ Confidence to overcome food insecurity } \\
\hline Yes & 59 & 38 \\
\hline No & 96 & 62 \\
\hline
\end{tabular}

Source: Field survey, 2014

smaller amount of food and $64.9 \%$ missed the number of meals per day.

\section{Household food security situation}

Table 4 reveals the distribution of respondents by household food insecurity situation (status) by using characteristics such as main source of food for the $\mathrm{HH}$ consumption, experience of borrowing money from informal rural money lenders for food purchase, trend of food insecurity in past few years, confidence to overcome food insecurity, capacity of $\mathrm{HH}$ to meet all-year round food requirements of $\mathrm{HH}$ members from own production and number of meals consumed by $\mathrm{HH}$ members per day.
Whether households depend on household food production or resort to market (is one interesting point to deal with), only $12.3 \%$ of the households reported that they stick to household production; $63.9 \%$ use the market and household production; $23.9 \%$ cover $\mathrm{HH}$ production, from market and through participating in PSNP. The respondents were also asked to report whether currently household faces food shortage or not. In this regard, majority of the respondents $(71.6 \%)$ reported their $\mathrm{HH}$ face food shortage, whereas $28.4 \%$ reported opposite.

It is also important to see how the householders perceive the food shortage. In this regard, it was reported by $75.5 \%$ of the respondents that food security situation is getting better in the last few years (see Table 4). The trend is defined to be worse for $8.4 \%$ of the respondents who have only one chicken. About $6.1 \%$ of them reported that there has not been significant change over the last few years and however, the quality and quantity of food consumption by HHs different the majority (69.7\%) of $\mathrm{HH}$ ate three times per day and $30.3 \%$ ate twice per day.

Table 4 reported that $54.9 \%$ of sample households borrowed money from informal rural money lenders and furthermore, $62 \%$ of sample households lacked confidence to escape from food insecurity trap.

\section{Household food security status}

Based on Household Food Insecurity Access Scale, nine questions calculation, Table 5 shows $71.6 \%$ of households were food insecure and $28.4 \%$ of households were food secure. This high food insecurity is due to the population number which is high in the study area.

\section{Empirical results and discussion of determinants of household food insecurity}

This section presents results and discussions of findings on food insecurity and its determinants. The effects on household food insecurity and interpretations of significant explanatory variables of logistic regression model analysis are as the followings.

Hence, Table 6 presents a summary of the raw score binary logistic regression coefficients, Wald statistics, $p$ values, odds ratios (Exp (B) and CI. The effects on household food insecurity and interpretations of significant explanatory variables of logistic regression model analysis are as the followings:

Table 6 reveals that household size was significantly and positively associated with food insecurity at $p$ value of 0.019. This indicates that large household size more likely to be food insecure than small household size ("EXP" $=2.113$, and (95\% CI) (1.129-3.955). According to empirical evidences in the previous works, in developing countries, subsistence agricultural production with 
Table 4 Percentage distribution of households by number of livestock owned

\begin{tabular}{|c|c|c|c|c|c|c|}
\hline \multirow[t]{2}{*}{ Characteristics } & \multicolumn{6}{|c|}{ Number of livestock owned } \\
\hline & 0 & 1 & 2 & 3 & 4 & $5+$ \\
\hline Ox & 41.9 & 42.6 & 13.5 & 1.9 & 0 & 0 \\
\hline Bull & 51.6 & 34.8 & 13.6 & 0 & 0 & 0 \\
\hline Cow milking & 57.4 & 23.9 & 14.8 & 3.9 & 0 & 0 \\
\hline Cow non-milking & 31 & 28.7 & 23.9 & 3.2 & 1.3 & 1.9 \\
\hline Heifer & 39.4 & 32.3 & 18.7 & 9.7 & 0 & 0 \\
\hline Sheep & 71 & 16.8 & 12.3 & 0 & 0 & 0 \\
\hline Goat & 96.8 & 3.2 & 0 & 0 & 0 & 0 \\
\hline Donkey & 91 & 9 & 0 & 0 & 0 & 0 \\
\hline Mule & 98.7 & 1.3 & 0 & 0 & 0 & 0 \\
\hline Horse & 98.7 & 1.3 & 0 & 0 & 0 & 0 \\
\hline Chicken & 63.9 & 8.4 & 21.3 & 6.5 & 0 & 0 \\
\hline
\end{tabular}

Source: Field survey, 2014

Table 5 Distribution of respondents by household food insecurity indicators (access scale)

\begin{tabular}{|c|c|c|}
\hline Characteristics (reference period of 4 weeks) & Frequency & Percent \\
\hline \multicolumn{3}{|l|}{ Worry about food shortage during the last 4 weeks } \\
\hline Yes & 108 & 69.9 \\
\hline No & 47 & 30.1 \\
\hline \multicolumn{3}{|l|}{ Inability to eat the preferred food } \\
\hline Yes & 111 & 71.6 \\
\hline No & 44 & 28.4 \\
\hline \multicolumn{3}{|l|}{ Eaten a limited variety of food } \\
\hline Yes & 106 & 68.3 \\
\hline No & 49 & 31.7 \\
\hline \multicolumn{3}{|c|}{ Unable to eat the preferred variety of food due to lack of resources } \\
\hline Yes & 74 & 48 \\
\hline No & 81 & 52 \\
\hline \multicolumn{3}{|l|}{ Eaten smaller amount of food } \\
\hline Yes & 103 & 66.4 \\
\hline No & 52 & 33.6 \\
\hline \multicolumn{3}{|l|}{ Ever missed a number of meals per day } \\
\hline Yes & 101 & 64.9 \\
\hline No & 54 & 35.1 \\
\hline \multicolumn{3}{|l|}{ Ever no food to eat } \\
\hline Yes & 0 & 0 \\
\hline No & 155 & 100 \\
\hline \multicolumn{3}{|l|}{ Sleeping without eating any food } \\
\hline Yes & 0 & 0 \\
\hline No & 155 & 100 \\
\hline \multicolumn{3}{|c|}{ Spending the day and night without eating any food during the last 4 weeks } \\
\hline Yes & 0 & 0 \\
\hline No & 155 & 100 \\
\hline
\end{tabular}

Source: Field survey, 2014 
Table 6 Results of logistic regression analysis for selected explanatory variables on food insecurity

\begin{tabular}{|c|c|c|c|c|c|c|c|c|}
\hline \multirow[t]{2}{*}{ Variables } & \multirow[t]{2}{*}{ B } & \multirow[t]{2}{*}{ SE } & \multirow[t]{2}{*}{ Wald } & \multirow[t]{2}{*}{$d f$} & \multirow[t]{2}{*}{ Sig. } & \multirow[t]{2}{*}{$\operatorname{Exp}(B)$} & \multicolumn{2}{|c|}{$95 \mathrm{Cl}$ for $\operatorname{EXP}(\mathrm{B})$} \\
\hline & & & & & & & Lower & Upper \\
\hline HH Size & 0.748 & 0.320 & 5.467 & 1 & 0.019 & 2.113 & 1.129 & 3.955 \\
\hline Livestock number & -1.351 & 0.477 & 8.005 & 1 & 0.005 & 0.259 & 0.102 & 0.660 \\
\hline Educational level of $\mathrm{HH}$ head & -5.626 & 1.3229 & 17.934 & 1 & 0.000 & 0.004 & 0.000 & 0.049 \\
\hline Sex of HH head & 0.994 & 0.556 & 3.203 & 1 & 0.075 & 2.703 & 1.910 & 6.032 \\
\hline Age of HH head's & 0.391 & 0.193 & 4.099 & 1 & 0.043 & 1.479 & 1.013 & 2.159 \\
\hline Small land size & 0.755 & 0.321 & 5.526 & 1 & 0.019 & 2.128 & 1.134 & 3.993 \\
\hline Not using credit use by the $\mathrm{HH}$ & 0.343 & 0.195 & 3.102 & 1 & 0.078 & 1.409 & 0.962 & 2.064 \\
\hline Lacking confidence of $\mathrm{HH}$ & 0.609 & 0.205 & 8.839 & 1 & 0.003 & 1.839 & 1.231 & 2.747 \\
\hline $\begin{array}{l}\text { Borrowing money from informal rural } \\
\text { money lenders }\end{array}$ & 1.150 & 0.503 & 5.222 & 1 & 0.022 & 3.157 & 1.178 & 8.463 \\
\hline Marital form & 0.139 & 0.110 & 1.602 & 1 & 0.206 & 1.150 & 0.926 & 1.427 \\
\hline Not using agricultural inputs & 1.008 & 0.303 & 11.098 & 1 & 0.001 & 2.740 & 1.514 & 4.959 \\
\hline Distance to the market & 0.130 & 0.084 & 2.423 & 1 & 0.120 & 1.39 & 0.967 & 1.341 \\
\hline Not involving petty trade & 1.229 & 0.400 & 9.447 & 1 & 0.002 & 3.417 & 1.561 & 7.480 \\
\hline
\end{tabular}

limited participation in non-agricultural activities, large household size exerts more pressure on consumption than the labor it contributes to production. The per capita food availability declines as family size increases due to population growth. Hence, large family size is more likely related to being food insecure in a household [14].

Logistic regression indicates that lacking livestock was significantly and positively associated with food insecurity at $p$ value of 0.005 . This association shows that household which lacked livestock was more likely to be food insecure than household which owned livestock $(\mathrm{EXP}=1.758$ and $95 \%$ CI 1.181-2.617). Previous study reveals, livestock possession is crucial to reduce food insecurity [15]. According to this study, lacking livestock is one of the fundamental determinants of food insecurity in the study area.

Educational level of HH head was significantly associated with food insecurity at $p$ value of 0.000 . Analysis of logistic regression indicates, educated household was less likely to be food insecure than household headed by uneducated (EXP $=2.075,95 \%$ CI $1.294-3.326)$. Educational level of the household heads could also have an influence on the food security status of the households. Educational attainment by the household head could lead to awareness of the possible advantages of modernizing agriculture by means of technological inputs; enable them to read instructions on fertilizer packs and diversification of household incomes which, in turn, would enhance households' food supply [16]. According to this study, illiterate-headed household is more expose to food insecurity.

Age of household head was significantly and positively associated with food insecurity at $p$ value of 0.043 . The analysis of logistic regression predicts household which headed by aged one is more likely to be food insecure than households headed by young or productive age $(\mathrm{EXP}=1.479$ and $95 \% \mathrm{CI} 1.013-2.159)$. The prediction here indicates household headed be higher aged (nonproductive aged); household has more chance to be food insecure in the study area. Other study reveals that age of household head is positively significant to food insecurity [17].

According to logistic regression analysis, small land size of household was significantly and positively associated with food insecurity at $p$ value of 0.019 . This association reveals that households owned small land size are more likely to be food insecure than households which owned large land size (EXP $=2.128$ and $95 \%$ CI $1.134-$ 3.993). Land holding size is considered a critical production factor that determines the type of crops grown and the size of crop harvests. Therefore, under subsistence agriculture, holding size is expected to play a significant role in influencing farm households' food security [18].

Lacking confidence to escape from food insecurity was significantly associated with food insecurity at $p$ value of 0.003. Logistic regression analysis indicates households which lacked confidence to escape from food insecurity were more likely to be food insecure than household which owns confidence to escape from food security $(\mathrm{EXP}=1.839$ and $95 \% \mathrm{CI} 1.231-2.747)$. A study conducted by Frankenberger [19] showed that chronically food insecure households were characterized by low motivation and confidence in regard to changing their chronic food insecurity [20]. Therefore, they experienced with chronic food insecurity $[21,22]$. According to this study, greater portion (62\%) of food insecure households 
are lacking confidence to escape from food insecurity trap because they fear for risk of investment, the experienced with food insecurity and they lacked capacity for investment.

Borrowing money from informal rural money lenders was significantly and positively associated with food insecurity at $p$ value of 0.022 . Positive association indicates household which borrowed money from informal money lenders was more likely to be food insecure compared to household which did not borrow money from informal money lenders $(\mathrm{EXP}=3.157$ and $95 \% \mathrm{CI}$ 1.178-8.463). Study conducted by Kadale Consultants [23] reported that poor farmers eroded assets through borrowing money from informal rural money lenders by $75-100 \%$ interest rate per month repayment rate. In this case, money lenders extracted economic surplus, such as poor farmer labor, capital and possibly land [24] quoting Von-Pischike (1991). This study indicates that majorities (54.9\%) of households experience borrowing money from informal rural money lenders as immediate solution for challenges they faced. So that households, which experienced borrowing money from informal rural money lenders, have more chance to be affected by food insecurity.

None use of agricultural inputs continuously was significantly associated with food insecurity at $p$ value of 0.001. Logistic regression analysis indicates that household which did not use agricultural inputs continuously was more likely to be food insecure compared to households which used agricultural inputs $(\mathrm{EXP}=2.740$ and 95\% CI 1.514-4.95). MoARD [25] discussed that poor farmers did not use agricultural inputs because of lack of sufficient income, high costs of inputs for smallholder farmers, inefficient agricultural inputs supply and distribution system and large-sized package of inputs for smallholder farmers. According to this study, households which do not use agricultural inputs have more chance to be food insecure than the households which use agricultural inputs continuously as recommended.

Low household income was significantly and positively associated food insecurity at $p$ value of 0.002 . According to this analysis, household with low income was likely to be food insecure compared to household with average and more income (EXP $=2.075$ and $95 \%$ CI 1.294-3.326). The amount of household low income was hypothesized to have negative influence on food insecurity [26]. Based on this study, households that have less opportunity to access better income are less likely to become food insecure than those households who had no or little access.

The analysis of logistic regression indicates that not participating on petty trading was significantly and positively associated with food insecurity at $p$ value of 0.002. Based on this analysis household which did not participate on petty trading was more likely to be food insecure than household which did not participate on petty trading $(E X P=3.417$ and $95 \%$ CI $1.56-7.480)$. The previous study shows off-farm income opportunities that are important means of securing food security [27]. Based on this study, not participating on petty trading is influencing household food security status.

\section{Conclusions}

The findings of the study revealed that $71.6 \%$ of the households are food insecure through the use of Household Food Insecurity Access Scale measurement.

These food insecure households could not cover the required daily food from the income generated from their major activity of subsistence agriculture and nonfarm activities both in quality and quantity.

Households with large family size, non-educated and old household heads are more likely to be food insecure than those with smaller family size, educated and young household heads. Similarly low land size, not livestock, not having confidence to overcome food insecurity of household, borrowing money from informal rural money lenders and not using farm input by the households are significantly associated with food insecurity. In whole, household-related factors determine household food insecurity through influencing own production, stocks and household purchasing power of food in study area.

\section{Recommendations}

- Creating sufficient awareness to affect family planning in the rural households.

- Strengthening the inter-resettlement programs was appropriate, in order to enhance food security through the setting aside of adequate areas of agricultural lands and other natural resources for the production of food and other sources of income.

- Grassroots organizations with ability to bring credit supply together, the resources, technology and knowledge must be supported and strengthened in order to enhance food shortage coping mechanisms.

- Timely delivery of inputs and long-term credit service facilitation are important.

- Livestock sector development should be a priority to help alleviate food insecurity.

- Increase employment opportunities, particularly in rural areas, by encouraging the private sector to augment such opportunities in agriculture, industry, handicraft and business.

- Improve the access and control of strategic resources such as land, cattle, cash crops, and other household assets. 


\section{Abbreviations}

CSA: Central Statistical Agency; EDHS: Ethiopian demographic and health survey; FAO: Food and Agriculture Organization; FGD: Focus group discussion; FSP: Food security program; HFIAS: Household Food Insecurity Access Scale; HHs: Households; MOARD: Ministry of agriculture and rural development; PSNP: Productive safety net program; SNNPRS: Southern Nation Nationalities Peoples Regional State; SPSS: statistical package for the social science; USAID United States Agency for International Development; WADO: Woreda Agricultural Development Office; WFP: World Food Programme.

\section{Acknowledgements}

Above all, our praises goes to Almighty God for all uncountable support and advice from start to end of this thesis. We would like to express our heartfelt gratitude to those who have helped us substantiate our research. That was unforgettable in our life. Furthermore, I would like to thank staff members of Damot Gale Woreda Agriculture Office for providing the required data for my study starting from the Woreda experts up to agricultural DA's in each of the study Kebeles.

\section{Authors' contributions}

AA participated in data collection, supervision, analysis, description and drafted the manuscript. ST analyzed logistic regression part and revised the manuscript. YH participated in data supervision, clark, logistic regression analysis, discussion writing and manuscript preparation. All authors read and approved the final manuscript.

\section{Funding}

Self-sponsored for research work.

\section{Availability of supporting data}

Not applicable.

\section{Ethical approval and consent to participate}

Prior to starting the work, the study design was explained to Officials of Agriculture department and Administrative of Damot Gale Woreda for their permission and support. The nature of the study was fully explained to respondents to obtain consent. No false promise such as remuneration and or per diem, food and financial aids was given. Information was collected after securing consent from study participant. Data obtained from each study participant were kept confidential, and all peoples who participated in the study were acknowledged. The consent form has been read to me and voluntarily I agree to participate in this study.

\section{Consent for publication}

Not applicable, because there is no data contained within our manuscript from which individual patients or participants may be identified.

\section{Competing interests}

The authors declare that they have no competing interests.

Received: 19 February 2016 Accepted: 29 April 2019

Published online: 28 May 2019

\section{References}

1. Food and Agricultural Organization (FAO). The state of food insecurity in the world 2013. The multiple dimensions of food security. Rome: FAO; 2013.

2. Food and Agricultural Organization (FAO). The state of food insecurity in the world 2010. Addressing food insecurity in protracted crises. Rome; FAO; 2010.

3. United States Agency for International Development (USAID). Tackling food insecurity and malnutrition in Ethiopia through diversification. 2012. Www.sweetpotatoknowledge.org. Accessed 3/2/2014.

4. WADO. Woreda agriculture and development office information and documentation process. 2010.
5. Damot Gale woreda in wolaita zone southern Ethiopia main administrative office. 2014.

6. Le Gal E, Molinier N. Agricultural and economic analysis-diagnosis of Obe Jage (Damot Gale, Wolayta). Institut National Agronomique ParisGrignon; 2006.

7. CSA, Central Statistical Agency. Addis Ababa, Ethiopia population profile. Eastern Commission; 2007.

8. Onwuegbuzie. Toward a definition of mixed methods research. J Mixed Methods Res. 2007:1:112-33.

9. Cochran WG. Sampling techniques. New York: Wiley; 1963.

10. Yamane T. Statistics, an introductory analysis. 2nd ed. New York: Harper and Row; 1967.

11. Radimer KL, Olson CM, Greene JC, Campbell CC, Habicht JP. Understanding hunger and developing indicators to assess it in women and children. J Nutr Educ. 1992;24:36-45.

12. Ethiopia Central Statistical Agency. Ethiopia demographic and health survey 2011: preliminary report. Addis Ababa; 2011, pp. 6-12.

13. Coates J, Swindale A, Bilinsky P. Household Food Insecurity Access Scale (HFIAS) for measurement of household food access: indicator guide, vol 3; 2007. Washington: Food and Nutrition Technical Assistance Project, Academy for Educational Development.

14. Paddy F. Gender differentials in land ownership and their impact on household food security: a case study of Masaka District, MA Dissertation, Uganda Press, Baltimore and London; 2003. http://www.troz.unihohenhe im.de/research/Thesis. Retrieved 5th Dec 2015.

15. WFP. Food security bulletin: food security monitoring system. Rome: Yamane; 2008

16. Najafi B. An overview of current land utilization systems and their contribution to agricultural productivity. Report of the APO Seminar on Impact of Land Utilization Systems on Agricultural Productivity.Productivity Organization, Islamic Republic of Iran Asian. 2003.

17. Ojogho O. Determinants of food insecurity among arable farmers in Edo state, Nigeria. 2009.

18. Degefa T. Household seasonal food insecurity in Oromiya Zone, Ethiopia: Causes. 2002. http://www.ossrea.net/ssrr/no26/no26-01.htm.

19. Frankenberger TR, Sutter $P$, Teshome A, Aberra A, Tefera M, Tefera M, Taffesse AS, Bernard T, Spangler T, Ejigsemahu Y. Ethiopia: the path to self-resiliency volume II: regional specific findings. Ethiop J Agric Econ. 2007;2(2):61-89.

20. Slater R, Ashley SS, Teferea M, Buta M, Esubalehu D. Ethiopian productive sefitnet program: study on policy, program and institutional linkage. In reginal consultation workshops. 2006. Addis Sbaba, September 2006, pp. $1-55$.

21. Nigatu R. Small holder farmers coping strategies to household food insecurity \& hunger in southern Ethiopia. Ethiop J Environ Stud Manag. 2011:4(1):42.

22. MoARD. Productive safety net programme: programme implementation manual, revised. Addis Ababa: MoARD; 2006.

23. Kadale Consultants. Final report of study on informal and non-formal rural financial services. 2012. Malawi.

24. Adebayo $\bigcirc 0$, Adeola RG. Sources and uses of agricultural credit by small scale farmers in Surulere Local Government Area of Oyo State. Anthropologist. 2008;10(4):313-4.

25. MoARD. Productive safety net programme: programme implementation manual, Revised. 2010. Addis Ababa, Ethiopia.

26. Bogale A, Shimelis. Household level determinants of food insecurity in rural areas of Dire Dawa, Eastern Ethiopia. 2009.

27. Amha W. Revisiting the regulatory and supervision framework of the microfinance industry in Ethiopia. In: Proceedings from a Seminar Organised by the Relief Society of Tigray (REST), on behalf of the Drylands Coordination Group in Ethiopia and Sudan, In Mekelle, August 25, 2001. 2004. DCG/Noragric, Agricultural University of Norway.

\section{Publisher's Note}

Springer Nature remains neutral with regard to jurisdictional claims in published maps and institutional affiliations. 